Vol. 04, No.02, Oktober 2018

Doi: 10.24198/cosmogov.v2i2.xxxxx

\title{
MANAJEMEN PEMERINTAHAN DALAM PEMBANGUNAN DESA DI DESA LEMAHABANG KECAMATAN LEMAHABANG KABUPATEN KARAWANG
}

\author{
Hanny Purnamasari ${ }^{1}$ \\ Rachmat Ramdani $^{2}$ \\ ${ }^{\text {I}}$ Program Studi Ilmu Pemerintahan, FISIP, Universitas Singaperbangsa Karawang \\ ${ }^{2}$ Program Studi Ilmu Pemerintahan, FISIP, Universitas Singaperbangsa Karawang \\ Email: hanny.purnamasari@fisip.unsika.ac.id
}

\begin{abstract}
ABSTRAK
Undang-Undang Nomor 6 tahun 2014 tentang Desa diharapkan dapat membawa paradigma baru dalam pembangunan, mampu mengubah cara pandang pembangunan, bahwa kesejahteraan dan kemakmuran ekonomi tidak selamanya berada di kota atau perkotaan, tetapi dalam pembangunan yang merata semua lapisan masyarakat yang dimulai dari pemerintahan desa. Penelitian ini menggunakan metode deskriptif dengan pendekatan kualitatif. Teknik pengumpulan data yang dilakukan dengan observasi, wawancara, dokumentasi dan studi pustaka. Peneliti menggunakan teknik purposive sampling dengan informan Kepala Desa Lemahabang, Sekdes Desa Lemahabang, Kaur Ekonomi dan Pembangunan, Kepala Dusun dan dua orang masyarakat Desa lemahabang. Hasil dari penelitian ini menunjukan bahwa manajemen pemerintahan dalam pembagunan desa di Desa Lemahabang dilihat dari perencanaan belum efektif karena masih kurangnya sosialisasi kepada masyarakat tentang rencana pembangunan desa, dalam penggorganisasian manajemen pembangunan desa masih belum efektif, hal ini terlihat dari sumber daya manusia aparatur pemerintah belum sesuai dengan kompetensi yang dimiliki, dalam penggerakan belum efektif karena belum adanya kejelasan tentang teknis pembangunan desa serta berapa lama pembanunan desa akan dilaksanakan dan dalam pengawasan juga masih belum efektif, hal ini terlihat dari belum ada tindak lanjut dari hasil pengawasan yang telah dilakukan baik baik internal maupun eksternal sehingga hasil dari pembangunan desa belum dapat diketahui.
\end{abstract}

Kata kunci: manajamen pemerintahan, pembangunan desa, Lemahabang

\section{ABSTRACT}

Law Number 6 of 2014 concerning Villages is expected to bring a new paradigm in development, be able to change the perspective of development, that economic prosperity and prosperity are not always in cities or cities, but inequitable development all layers of society starting from village government. This study uses a descriptive method with a qualitative approach. Data collection techniques carried out by observation, interviews, documentation, and literature. The researcher used a purposive sampling technique with informants from the Head of the Village of Lemahabang, the Village Secretary of Lemahabang Village, the Head of Economy and Development, the Head of the Village and two people from 
Vol. 04, No.02, Oktober 2018

Doi: 10.24198/cosmogov.v2i2.xxxxx

the village of Weakabang. The results of this study indicate that government management in village development in Lemahabang Village is seen from the planning as not yet effective because there is still a lack of socialization to the community regarding village development plans, in the organization of village development management it is still not effective with the competencies possessed, the mobilization has not been effective because there is no clarity about the technical development of the village and how long the village development will be carried out and in supervision it is still not effective, this can be seen from the lack of follow-up results of supervision both internal external so that the results of village development have not been known.

Keywords: management of governament; rural development; lemahabang

\section{PENDAHULUAN}

Ditetapkannya Undang-Undang Nomor 6 tahun 2014 tentang Desa diharapkan dapat membawa paradigmabaru dalam pembangunan, mampu mengubah cara pandang pembangunan, bahwa kesejahteraan dan kemakmuran ekonomi tidak selamanya berada di kota atau perkotaan, tetapi dalam pembangunan yang merata semua lapisan masyarakat yang dimulai dari pemerintahan desa. Desa menjadi bagian terdepan dari upaya gerakan pembangunan yang berasal dari prakarsa masyarakat, guna mencapai kesejahteraan dan kemakmuran, sekaligus berkeadilan dan berkesinambungan.

Berdasarkan dari peraturan undang-undang nomor 6 tahun 2014 tentang pemerintahan desa dalam pasal 78 menyatakan bahwa yang dimaksud dengan pembangunan desa yaitu bertujuan untuk meningkatkan kesejahteraan masyarakat desa dan kualitas hidup manusia serta penanggulangan kemiskinan melalui pemenuhan kebutuhan dasar, pembangunan saranan dan prasarana desa, pengembangan potensi ekonomi lokal serta pemanfaatan sumber daya alam dan lingkungan secara berkelanjutan. Selain itu dijelaskan bahwa dalam pembangunan desa harus mengedepankan kebersamaan, kekeluargaan dan gotong royong guna mewujudkan keadialan sosial.

Penelitian ini dilatarbelakangi oleh program-program pembangunan desa yang kurang adanya keterlibatan masyarakat dalam perencanaan pembangunan masih mendominasi oleh pihak pemerintahan dalam perencanaan pembangunan. Hal ini terjadi di Desa lemahabang dalam perencanaan pembangunan masih didominasi oleh pihak pemerintahan kurang adanya keterlibtan masyarakat dalam perencanaan pembangunan Desa Lemahabang masih rendahnya sumber daya manusia.

Desa Lemahabang Kecamatan Lemahabang Kabupaten Karawang dalam melaksanakan program pembangunan selama ini belum mampu meningkatkan partisipasi masyarakat dalam perencanaan pembangunan. Berdasarkan 
Vol. 04, No.02, Oktober 2018

Doi: 10.24198/cosmogov.v2i2.xxxxx

latarbelakang diatas tersebut, maka dari itu peneliti tertarik untuk lebih lanjut dan mendalami dalam penelitian ini yang berjudul "Manajemen Pemerintahan Dalam Pembangunan Desa Di Desa Lemahabang Kecamatan Lemahabang Kabupaten Karawang”.

\section{RUMUSAN MASALAH}

1. Bagiamana perencanaan dalam manajemen pembangunan Desa Lemahabang?

2. Bagiamana Pengorganisasian dalam manajemen pembangunan Desa Lemahabang?

3. Bagaiamana pengunaan sumbersumber daya dalam manajemen pembangunan

Desa Lemahabang?

4. Bagaimana kontrol dalam manajemen pembangunan desa Lemahabang?

\section{TINJAUAN PUSTAKA}

\section{a. Manajemen}

Menurut Hasibuan (2006:9) manajemen adalah ilmu dan seni mengatur proses pemanfaatan sumber dan manusia dan sumber-sumber lainnya secara efektif dan efisien untuk mencapai suatu tujuan tertentu. Lain lagi halnya manajemen menurut Sirkula (dalam Hasibuan, 2006:2) adalah: "Management in general refers to planning, organizing, controlling, staffing, leading, motivating, commucating, and decision making activities performed by organization in order to coordinate the varied resource of enterprise so as to bring an effect creation of some product or service."

Manajemen pada umumnya dikaitkan dengan aktivitas-aktivitas perencanaan, pengorganisasian, pengendalian, penempatan, pengarahan, pemotivasian, komunikasi, dan pengambilan keputusan yang dilakukan oleh setiap organisasi dengan tujuan untuk mengkoordinasi berbagai sumber daya yang dimiliki perusahaan sehingga akan dihasilkan suatu produk atau jasa secara efisien)".

Sinabela (2016:3) menyatakan dalam berbagai kepustakaan dikenal dengan konsep "6M" yaitu man, money, material, machine, metode dan market. Sumber daya manusia dalam setiap organisasi baik publik maupun bisnis, adalah sumber daya yang utama, disamping berbagai sumber daaya yang lainnya.

Menurut peneliti manajemen dapat pula diartikan sebagai kegiatan mengurus, membimbing serta mengarahkan agar suatu tujuan dapat tercapai. Suatu tujuan dari organisasi dapat dicapai dengan banyak aspek yang menjadi penentu yang terikat satu sama lainnya, diantaranya adalah pemimpin yang profesional, sarana yang memadai, waktu yang tersedia, dana yang mencukupi, dan dilaksanakan melalui tata pelaksanaan manajemen yang baik.

\section{b. Manajemen Pemerintahan}

Ndraha (2003:160) melanjutkan bahwa manajemen menunjukan fungsifungsi yang dijalankan terus menerus dan berturut-turut untuk mencapai 
Vol. 04, No.02, Oktober 2018

Doi: 10.24198/cosmogov.v2i2.xxxxx

suatu sistem nilai yang disebut efektivitas, efisiensi dan produktivitas. Adapun fungsi-fungsi manajemen pemerintahan yang dimaksud Ndraha adalah sebagai berikut :

1. Perencanaan pemerintahan. Dilakukan untuk mengklarifikasi tujuan organisasi dan menyusun langkah-langkah guna mencapai tujuan yang kongkrit dan terukur.

2. Pengorganisasian sumbersumber pemerintahan adalah realisasi langkah-langkah tersebut memerlukan sumber daya, sebelum digunakan harus diorganisir agar siap pakai.

3. Penggunaan sumber-sumber pemerintahan dilakukan untuk mengerakan sumber-sumber pemerintahan agar mendapatkan hasil-hasil yang sudah ditetapkan.

4. Kontrol pemerintahan adalah dilakukan untuk menjamin kesesuaian antara target pada perencanaan dengan hasil yang diperoleh dari penggunaan sumber-sumber pemerintahan daya tersebut.

\section{c. Manajemen Pemerintahan}

Waluyo (2007:119) mengartikan manajemen pemerintahan sebagai berikut: Secara konseptual dari dua istilah di atas (manajemen dan pemerintahan) dapat disimpulkan bahwa manajemen pemerintahan mengandung arti sebagai suatu kegiatan atau usaha untuk mencapai tujuan-tujuan negara dengan menggunakan sumber-sumber yang dikuasai negara.
Pengertian manajemen pemerintahan menurut Waluyo (2007:119) tersebut diperkuat dengan pendapat Ranto yang mendefinisikan manajemen pemerintahan sebagai faktor utama dalam suatu administrasi publik untuk mencapai tujuan yang telah ditetapkan dengan sarana dan prasarana yang ada, termasuk organisasi serta sumber dana dan sumber daya yang tersedia. Suharyadi, Heri dan Insani M, Aji (2016) menyebutkan manajemen pemerintahan juga menyoroti proses perencanaan, pengorganisasian, pelaksanaan, dan pengawasan yang dilakukan oleh pemerintah dalam rangka memberikan pelayanan kepada masyarakat.

Penyelenggaraan pemerintahan Indonesia di dalam kerangka negara kesatuan, antara pemerintah pusat dan pemerintah daerah di dalam pelaksanaannya tidak dapat dilepaskan dari penggunaan asas penyelenggaraan pemerintahan di daerah. UU No.23 Tahun 2014 tentang Pemerintahan Daerah yang pada prinsipnya mengatur penyelenggaraan pemerintahan daerah yang lebih mengutamakan pelaksanaan asas desentralisasi.

\section{METODE PENELITIAN}

Dalam penelitian ini peneliti menggunakan pendekatan kualitatif dimana dalam penelitian yang dilakukan bersifat deskriptif yaitu untuk mengetahui atau menggambarkan kenyataan dari kejadian yang diteliti sehingga memudahkan peneliti untuk 
Vol. 04, No.02, Oktober 2018

Doi: 10.24198/cosmogov.v2i2.xxxxx

mendapatkan data yang objektif dalam rangka untuk mengetahui Manajemen Pemerintahan Dalam Pembangunan di Desa Lemahabang Kecamtan Lemahabang Kabupaten Karawang.

Menurut Moleong (2005:6) penelitian kualitatif bermaksud untuk memahami fenomena tentang apa yang dialami oleh subyek penelitian misalnya, perilaku, persepsi, motivasi, tindakan, dan lain-lain secara holistik, dan dengan cara deskriptif dalam bentuk kata-kata dan bahasa pada suatu konteks khusus yang alamiah dan dengan memanfaatkan berbagai metode ilmiah.

\section{HASIL DAN PEMBAHASAN}

Berdasarkan hasil penelitian yang merupakan penjelasan mengenai data selama penelitian di lapangan terhadap Manajemen Pemerintahan Dalam Pembangunan Di Desa Lemahabang Kecamatan Lemahabang Kabupaten Karawang, diperoleh data dan informasi melalui wawancara mendalam terhadap informan yang ditemui dilapangan dan studi dokumentasi.

\section{Perencanaan Dalam Manajemen Pemerintahan Desa Dalam Pembangunan Desa di Desa Lemahabang}

Perencanaan merupakan susunan langkah-langkah secara sistematik dan teratur untuk mencapai tujuan organisasi atau memecahkan masalah tertentu. Perencanaan juga diartikan sebagai upaya memanfaatkan sumbersumber yang tersedia dengan memperhatikan segala keterbatasan guna mencapai tujuan secara efisien dan efektif. Perencanaan dalam pembangunan desa dengan mengunakan pendekatan bottom up yang dimulai dari mengindentifikasi permasalahan-permasalahan dan kebutuhan yang memang benar-benar yang dibutuhkan oleh masyarakat Desa Lemahabang.

Perencanaan pembangunan memang perlu mendapatkan dukungan dari partisipasi peran aktif masyarakat yang terlibat dalam perencanaan pembangunan yang akan oleh pemerintah desa, tanpa adanya ikut sertaan masyarakat pemerintah sulit untuk mengetahui apa saja yang memang dibutuhkan oleh masyarakat desa.

Oleh sebab itu, maka pembangunan yang direncanakan harus sesuai dengan kemauan masyarakat disamping dukungan dari partisipasi yang dimiliki masyarakat untuk menyukseskan setiap gerakan pembangunan yang akan dilaksanan. Berdasarkan hasil penelitian dilapangan menunjukan bahwa perencanaan pembangunan masyarakat desa yang dilaksanakan di Desa Lemahabang terdapat bentuk-bentuk partisipasi dari masyarakat yang memberikan masukan terkait perencanaan pembangunan yang akan dilaksanakan oleh pemerintah desa. Sebagaimana yang disampaikan oleh Kaur pembangunan Desa menyatakan dalam perencanaan pembangunan beliau menyatakan bahwa:

"Perencanaan dimulai dari awal tahun dilaksanakan yang disesuaikan 
Vol. 04, No.02, Oktober 2018

Doi: 10.24198/cosmogov.v2i2.xxxxx

dengan pengajuan dari setiap dusundusun yang mengajukan kebutuhan untuk satu tahun kedepan pembangunan, pengajuan tersebut dari masyarakat oleh kami pemerintah desa di input data-data atas pengajuan dari masyarakat yang diwakili oleh setiap dusun. Misalnya pembangunan atas pengajuan pembangunan infrastuktur jalan setelah data di input kami dari Desa melakukan survei lapangan atas pengajuan pembangunan infrastuktur tersebut". (Kantor Desa Lemahabang, 6 Sepetember 2017)

Perencanaan pembangunan bertujuan untuk memperbaiki kondisi kehidupan masyarakat untuk lebih baik, melalui langkah awal perencanan pembangunan untuk mencapai pertumbuhan masyarakat tentunya melalui pendekatan partisipasi dengan mendengarkan segala kebutuhan masyarakat sebagai acuan pelaksanaan pembangunan yang akan dilaksanakan oleh desa. Perencanaan pembangunan di desa melalui beberapa tahap, dari setiap tahapan yang dilaksanakan oleh pemerintah desa selalu melibatkan masyarakat sebagai objek pembangunan yang diberikan kesempatan untuk memberikan masukan atas pembangunan yang akan dilaksanakan oleh pemerintah desa hal ini diungkapkan oleh Sekretaris Desa Lemahabang menyatakan bahwa:

"Perencanaan pembangunan di desa tahapan pertama, dimulai dari Musrembang dusun mengindentifikasi setiap kebutuhan masyarakat di desa lemahabang ada empat dusun. Dari keempat dusun itu kami melaksanakan musrembang untuk menampung kebutuhan masyarakat untuk pembangunan yang akan dilaksanakan satu tahun kedepan maupun jangka panjang. Dilanjutkan dengan musrembang desa menentukan prioritas pembangunan yang akan dilaksanakan atas hasil dari musrembang dusun. Setelah itu musrembang kecamatan dari setiap musrembang desa disatukan untuk dibahas di musrembang kabupaten itulah tahapan perencanaan pembangunan di desa". (Kantor Desa Lemahabang, 6 September 2017)

Selain dari tahapan-tahapan pembangunan masyarakat desa di Lemahabang juga harus diperhitungkan landasan peraturan yang mengatur dalam rencana pembangunan. Pemerintah desa lemahabang sebagai pelaksanaan pembangunan masyarakat mempunyai peranan yang sangat penting terutama dalam hal pelaksanaan kebijakan berhubungan dengan program rencana pembangunan desa yang akan dilaksanakan di Desa Lemahabang, sebagaimana pernyataan dari Kepala Desa Lemahabang beliau menyatakan bahwa:

"Kami sebagai pelaksana pembangunan desa dari setiap tahapan-tahapan pembangunan mengacu pada peraturan yang ada seperti peraturan menteri dalam negeri nomor 66 tahun 2007 tentang perencanaan pembangunan dan undang-undang desa terbaru acuan kami dalam pelaksanaan 
Vol. 04, No.02, Oktober 2018

Doi: 10.24198/cosmogov.v2i2.xxxxx

pembangunan". (Kantor Desa Lemahabang, 6 September 2017)

Oleh sebab itu, setiap kebijakan yang akan dilaksanakan berkaitan dengan perencanaan pembangunan itu benar-benar dapat mengakomodir setiap aspirasi masyarakat sebagai dari objek pembangunan berkaitan dengan perencanaan pembangunan dalam setiap keputusan pengambilan keputusan untuk dijadikan pelaksanaan pembangunan. Berdasarkan hasil dari pengamatan penelitian dan wawancara mendalam dengan informan penelitian dapat disimpulkan bahwa dalam perencanaan pembangunan masyarakat desa sudah berjalan dengan baik dengan adanya beberapa tahapan yang dilaksanakan oleh Desa Lemahabang untuk mewadahi aspirasi masyarakat untuk pembangunan yang akan dilaksanakan oleh Pemerintah Desa. Selain itu, pemerintah Desa Lemahabang dalam perencanaan pembangunan hanya sebagai fasilitator pengajuan-pengajuan dari masyarakat setelah itu pemerintah desa menentukan skala prioritas pembangunan. Perencanaan pembangunan masyarakat desa sudah memiliki acuan dalam penyelenggaran perencanaan pembangunan desa, akan tetapi dalam perencanaannya belum melibatkan masyarakat. Selain itu pemerintah desa belum melakukan sosialisasi secara menyeluruh tentang rencana pembangunan yang ada di Desa Lemahabang sehingga perencanaan dalam manajemen pemerintahan dalam pembangunan desa belum efektif.

\section{Pengorganisasian Dalam Manajemen Pemerintahan Desa Dalam Pembangunan Desa di Desa Lemahabang}

Pengorganisasian diartikan sebagai kegiatan pembagian tugastugas pada orang yang terlibat dalam aktivitas organisasi, sesuai dengan kompetensi SDM yang dimiliki. Oleh karena itu dapat dikatakan bahwa kegiatan ini merupakan keseluruhan proses memilih orang-orang serta mengalokasikannya sarana dan prasarana untuk menunjang tugas orang-orang itu dalam organisasi, serta mengatur mekanisme kerjanya sehingga dapat menjamin pencapaian tujuan program dan tujuan organisasi.

Tahapan pembangunan masyarakaat desa lemahabang tidak hanya dilaksanakan oleh pemerintah desa tetapi ada pembagian tugas dalam menentukan prioritas pembangunan. Pembagian tugas tersebut untuk mendata semua keperluan dan kebutuhan dari setiap masyarakat. Tanpa adanya pembagian tugas dalam pembangunan masyarakat desa di Desa Lemahabang tidak akan terlaksana efektif karena Desa lemahabang keterbatasan dalam sumber daya manusia. Desa dalam mengakomodir aspirasi membagi tugas kepada setiap dusun untuk membuat musyawarah yang akan dihadiri oleh masyarakat dusun setempat untuk menentukan pembangunan di dusun tersebut sebagiamana yang diungkapkan oleh Kaur pembangunan Lemahabang menyatakan bahwa: 
Vol. 04, No.02, Oktober 2018

Doi: 10.24198/cosmogov.v2i2.xxxxx

"Pelaksanaan pembangunan membagi tugas, pemerintah desa di bantu oleh wakil wilayah dan ketua-ketua dusun yang membantu pelaksanaan pembangunan tanpa adanya pembagian tugas tidak akan sетиa terakomodir aspirasi. Saya kooridnasi dengan sekretaris desa dan kepala desa untuk melaporkan tahapan pembangunan". (Kantor Desa Lemahbang, 6 September 2017)

Dalam tahapan perencanaan maupun pelaksanaan pembangunan masyarakat desa di Lemahabang membagi tugas dan dibantu oleh masyarakat sebagai pemantuan pelaksaan dari pembangunan tersebut. Seperti perencanaan pembangunan infrastruktur tahapan pertama masyarakat yang terdiri dari wakil wilayah dan dusun mengukur berapa meter jalan yang akan diperbaiki setelah itu ditinjuan oleh Desa dan dibantu LPM untuk melihat kondisi dilapangan yang diperbaiki melalui anggaran desa dengan di bantu oleh aparatur desa dan masyarakat dusun setempat.

Pengorganisasian dalam pembangunan Desa Lemahabang dibantu oleh masyarakat misalkan untuk pembangunan bidang kesehatan kami bekerjasama dengan ibu-ibu posyandu mendata apa saja yang dibutuhkan untuk di bantuk oleh pemerintah desa seperti kebutuhan membangunan fasilitas posyadu, kelengkapan sarana dan prasarana untuk posyandu dan lain-lain. Sama halnya di bidang pendidikan pun kami bekerjasama dengan masyarakat yang mengelola seperti PAUD yang ada di Desa Lemahabang mendata semua kebutuhannya. Sebagaimana yang diungkapkan oleh Kepala Desa Lemahabang menyatakan bahwa:

"Selalu pembangunan di Desa Lemahabang sudah ditentukan presentasi-presentasi anggaran dari setiap bidangnya seperti bidang pendidikan, bidang kesehatan, bidang pendidikan dan bidang pembangunan semuanya udah di plot dianggarakan melalui kebijakan APBDes tahapan mengumpulkan data yang akan di biaya oleh Desa bekerjasama dengan masyarakat yang diundang ke Kantor Desa". (Kantor Desa Lemahabang, 6 September 2017)

Kelemahan dalam pengorganisasian pembangunan di Desa Lemahabang terletak di sumber daya manusianya sebagai pelaksana dari pembangunan masih rendah bisa dilihat berdasarkan dari komposisi pendidikan. Desa Lemahabang belum ideal dalam pembagian tugas sesuai dengan kemampuan keahlian di bidangnnya hal ini dikarenakan adanya keterbatasan dari minat masyarakat desa untuk menjadi aparatur desa. Berdasarkan hasil pengamatan di lapangan peneliti, menurut pandangan penelitian bahwa pengorganisasian pembangunan di Desa Lemahabang belum cukup berjalan dengan baik. Faktor penghambat dari pengorganisasian terletak dari sumber daya manusia yang akan melaksanakan dari pembangunan tersebut. Mekanisme pengorganisasian pembangunan Desa Lemahabang 
Vol. 04, No.02, Oktober 2018

Doi: 10.24198/cosmogov.v2i2.xxxxx

dengan mengundang masyarakat ke kantor desa untuk menyampaikan apa saja yang mereka butuhkan yang tertampung dalam draf musrembang dusun.

\section{Pergerakan Dalam Manajemen Pemerintahan Desa Dalam Pembangunan Desa di Desa Lemahabang}

Pengorganisasian menurut Terry dalam Syamsir Torang (2013:171), Actuating (penggerakan) meliputi kepemimpinan, koordinasi, pengawasan, dan perintah. Kepemimpinan yakni gaya memimpin dari sang pemimpin dalam mengoptimalkan seluruh potensi dan sumber daya organisasi agar mengarah pada pencapaian tujuan program dan organisasi. Sedangkan koordinasi yakni suatu aktivitas membawa orangorang yang terlibat organisasi ke dalam suasana kerjasama yang harmonis.

Kepemimpinan merupakan bagian terpenting dalam mencapainya sebuah tujuan dari suatu organisasi. Dalam hal ini kepemimpinan dalam pembangunan masyarakat desa lemahabang untuk mengoptimalisasikan seluruh potensi yang dimiliki oleh desa lemahabang baik sumber daya manusia maupun potensi sumber daya alam yang dapat dikembangkan untuk dijadikan pembangunan hasilnya akan dirasakan oleh masyarakat.

$$
\text { Pembangunan di desa }
$$

Lemahabang yang menjadi unggulan masih terfokus pada pembangunan fisik seperti pembangunan infrastuktur jalan di setiap dusun-dusun. Dalam kepemimpinan kepala desa saat ini memiliki keinginan untuk menyelesaikan kepemimpinannya fokus pada pembangunan merata infrastuktur jalan dari setiap dusunnya. Kepemimpinan mengoptimalkan semua para aparatur desa untuk mampu menggerakan pembangunan infrastuktur jalan dengan bekerjasama dengan masyarakat yang akan diperbaiki infrastuktur jalannya. Sebagaimana pernyataan dari kaur pembangunan menanggapi tentang kepemimpinan Kepala Desa Lemahabang mengatakan bahwa:

"Bukannya saya membaguskan kepala desa yah. emang beliau proaktif kalau dibandingkan dengan kepala desa yang lain. Pimpinan proaktif pelaksanaan pembangunan bahkan beliau sendiri terjun kelapangan untuk mendampingi proses pengukuran jalan yang akan diperbaiki tidak hanya menyerahkan kepada kami sebagai bawahan beliau ". (Kantor Desa Lemahabang, 6 September 2017)

Dalam menunjang keberhasilan dari proses pembangunan tidak lepas dari pengaruh kepemimpinan yang mengerakan aparatur pemerintah maupun masyarakatnya. Maka keberhasilan dari pembangunan masyarakat desa bukan saja diukur dari segi keberhasilan dalam pelaksanaan kebijakan atau penyelenggaran program pembangunan masyarakat tetapi bagaimana seorang pemimpin mampu menumbuh kembangkan partisipasi baik berupa dukungan penuh dari masyarakat maupun sumbangan-sumbangan lainnya yang 
Vol. 04, No.02, Oktober 2018

Doi: 10.24198/cosmogov.v2i2.xxxxx

dapat diberikan oleh masyarakat untuk menyukseskan pembangunan di desa. Sebagaimana yang dikemukan oleh masyarakat desa menyatakan bahwa :

"Bentuk partisipasi masyarakat sudah tinggi bisa dilihat dari musrembang dusun banyak warga yang ikut terlibat dalam perencanaan pembangunan, waktu pelaksanaan musrembang banyak yang kasih bantuan masukan untuk pembangunan di desa kebanyakan dari mereka ingin pembangunan infrastruktur jalan yang dirasakan masih banyak yang rusak jalan-jalan ke dusun ". (Kantor Desa Lemahabang, 6 September 2017)

Selanjutnya di sampaikan oleh masyarakat yang terlibat langsung dalam proses pelaksanaan pembangunan infrastuktur di Desa Lemahabang dalam menanggapi gaya kepemimpinan Kepala Desa Lemahabang beliau mengatakan bahwa:

"Yang saya rasakan Kepala Desa ketika memperbaiki jalan di Dusun Krajan beliau langsung mendampingi pengukuran bahkan beliau berkoordinasi dengan masyarakat setempat untuk mengupayakan agar di Dusun Krajan bisa masuknya mobil sekarang di Dusun Krajan bisa masuk mobil dan jalan udah diperbaiki ". (Kantor Desa Lemahabang, 6 September 2017)

Berdasarkan hasil pengamatan dan wawancara mendalam dengan informan menunjukan bahwa pengerakan dalam manajemen merupakan hal penting untuk menentukan keberhasilan dalam mencapai dari suatu tujuan. Dalam hal ini pengerakan dalam pembangunan masyarakat desa di Desa Lemahabang belum berjalan efektif. Jika dilihat dari gaya kepemimpinan Kepala Desa yang dapat bekerja secara maksimal dalam mengoptimalkan sumber daya manusia baik dari aparatur pemerintah maupun masyarakat untuk mendukung proses pelaksanaan pembangunan. Akan tetapi belum ada kejelasan mengenai siapa pelaksana pembangunan desa, berapa lama proses pembangunannya dan apa yang menjadi ukuran keberhasilan dalam pembangunan.

Pengawasan Dalam Manajemen Pemerintahan Desa Dalam Pembangunan Desa di Desa Lemahabang

Menurut Terry (dalam Torang, 2013:177) pengawasan sebagai bagian dari pengendalian akan mencatat perkembangan organisasi kearah tujuan yang diharapkan dan memungkinkan pemimpin mendeteksi penyimpangan dari perencanaan tepat pada waktunya untuk mengambil tindakan korektif sebelum terlambat dengan menentukan dan menetapkan apa yang harus dilakukan dan diharapkan.

Pengawasan dalam pelaksanaan pembangunan secara internal organisasi dilakukan oleh Badan Permusyawarahan Desa (BPD) Dan Lembaga Pemberdayaan Masyarakat (LPM) kedua lembaga tersebut yang mengawasi setiap pelaksanaan pembangunan yang diselenggarakan oleh pemerintah desa lemahabang. Sedangkan pengawasan secara ekternal 
Vol. 04, No.02, Oktober 2018

Doi: 10.24198/cosmogov.v2i2.xxxxx

dilakukan oleh masyarakat itu sendiri yang dapat mengawasi pelaksaan dari pembangunan yang diselenggarakan oleh pemerintah Desa Lemahabang pernyataan yang disampaikan oleh Sekretaris Desa menyatakan bahwa:

"Kepala desa selalu memberikan arahan ke semua aparatur pemerintahan agar pelaksaan pembangunan agar berjalan efektif karena desa saat ini banyak yang mengawasi makanya pimpinan selalu memberikan arahan agar program berjalan efektif. Nah yang sering menjadi kendala dalam proses pelaksanaan pembangunan desa ketika turun seтиa program pembangunan di setiap desa kita berebut untuk dapat bahan material untuk pembangunan karena turunnya program pembangunan di kabupaten berbarengan sedangkan di desa masih fokus utama pembangunan fisik". (Kantor Desa Lemahabang, 6 September 2017)

Kepala desa sangat menekankan kerjasama antar aparatur pemerintah agar pelaksanaan pembangunan berjalan efektif. Di Karawang saat ini sudah banyak kepala desa yang terjerat kasus korupsi maupun penyimpangan kewenangan yang dilakukan oleh kepala desa. Di desa lemahabang selama ini belum ada teguran dari pihak pengawasan terhadap pelaksanaan dari pembangunan desa berjalan sesuai dengan perencaan belum ada teguran dari LPM maupun BPD terkait dengan pelaksaan pembangunan.
Berdasarkan hasil wawancara dengan Kepala Desa menyatakan bahwa pelaksanaan pembangunan desa dilakukan oleh Desa beliau menyatakan bahwa:

"Masyarakat selalu mengangap bahwa desa itu banyak uang dari bantuan dari pemerintah kabupaten maupun pemerintah provinsi dan bantuan-bantuan lainnya, sedangkan kita sebagai pelaksanaan pembangunan bahwa anggaran yang ada di desa semua dialokasi untuk pembangunan plot anggaran $70 \%$ untuk pembangunan fisik sedangkan sisa nya pembangunan non fisik. Desa pun dalam pelaksaan pembangunan tidak lepas dari acuan aturan-aturan yang mengikat menjadi landasan pelaksaan". (Kantor Desa Lemahabang, 6 September 2017)

Dalam pelaksaan pembangunan desa yang banyak teguran dari pihak pengawasan pembangunan ekonomi simpan pinjem yang selalu menjadi sorotan oleh pihak pengawasan baik LPM maupun BPD program simpan pinjem. Karena simpan pinjem tersebut sering terjadinya tumpang tindih aturan selain itu masyarakat selalu menganggap bantuan dari pemerintah tidak perlu dikembalikan mereka menganggap bantuan modal tanpa harus memikirkan untuk mengembalikan uang tersebut. Sedangkan program simpan pinjam itu sebagai upaya pemerintah melakukan pemberdayaan untuk masyarakat agar dapat kemandirian dalam bidang ekonomi. Desa Lemahabang untuk beberapa tahun terakhir tidak ada 
Vol. 04, No.02, Oktober 2018

Doi: 10.24198/cosmogov.v2i2.xxxxx

program bidang ekonomi simpan pinjem akan mendeteksi adanya penyimpangan dalam pelaksanaannya sedangkan aparatur pemerintah desa bekerja selalu diawasi oleh masyarakat secara langsung maupun pihak kelembagan BPD dan LPM. Berdasarkan hasil pengamatan penelitian, pengawasan dalam pembangunan merupakan hal yang terpenting dari manajemen pembangunan karena tanpa adanya pengawasan maka pelaksanaan pembangunan akan banyak terjadinya penyimpangan. Dalam hal ini pengawasan dalam pembangunan masyarakat Desa Lemahabang belum efektif. Pelaksaan pembangunan masyarakat desa di Lemahabang untuk pembangunan sudah berjalan di semua dusun, akan tetapi belum ada tindak lanjut dari hasil pengawasan yang telah dilakukan baik baik internal maupun eksternal sehingga hasil dari pembangunan desa belum dapat diketahui apakah masyarakat dapat menikmati hasilnya atau tidak.

\section{KESIMPULAN}

Adapun kesimpulan yang dapat ditarik dari hasil penelitian ini adalah sebagai berikut:

Perencanaan dalam pembangunan masyarakat Desa Lemahabang belum efektif. Hal ini terlihat dari Perencanaan pembangunan masyarakat desa sudah memiliki acuan dalam penyelenggaran perencanaan pembangunan desa, akan tetapi dalam perencanaannya belum melibatkan masyarakat. Selain itu pemerintah desa belum melakukan sosialisasi secara menyeluruh tentang rencana pembangunan yang ada di Desa Lemahabang sehingga perencanaan dalam manajemen pemerintahan dalam pembangunan desa belum efektif.

Pengorganisasian dalam

pembangunan masyarakat Desa Lemahabang belum begitu berjalan dengan baik, hal ini dapat dilihat dari kelemahan pengorganisasian terletak dari sumber daya manusia aparatur pemerintah belum sesuai dengan kompetensi yang dimiliki sehingga pembagian kerja dalam pelaksaan pembangunan belum berjalan dengan optimal.

Pengerakan dalam pembangunan masyarakat Desa Lemahabang belum berjalan efektif. Jika dilihat dari gaya kepemimpinan Kepala Desa yang dapat bekerja secara maksimal dalam mengoptimalkan sumber daya manusia baik dari aparatur pemerintah maupun masyarakat untuk mendukung proses pelaksanaan pembangunan. Akan tetapi belum ada kejelasan mengenai siapa pelaksana pembangunan desa, berapa lama proses pembangunannya dan apa yang menjadi ukuran keberhasilan dalam pembangunan.

Pengawasan dalam pembangunan masyarakat Desa Lemahabang belum efektif. Pelaksanaan pembangunan masyarakat desa di Lemahabang untuk pembangunan sudah berjalan di semua dusun, akan tetapi belum ada tindak lanjut dari hasil pengawasan yang telah dilakukan baik baik internal maupun eksternal sehingga hasil dari 
Vol. 04, No.02, Oktober 2018

Doi: 10.24198/cosmogov.v2i2.xxxxx

pembangunan desa belum dapat diketahui apakah masyarakat dapat menikmati hasilnya atau tidak.

Kepala Desa dalam menjalankan program pembangunan harus melibatkan masyarakat agar tercipta suatu hubungan dan kinerja yang baik antara pemerintah desa dengan masyarakat, disamping itu juga akan membuat masyarakat merasa bertanggung jawab atas pembangunan tersebut serta akan memelihara akan hasil pembangunan dengan sebaikbaiknya.

Kepala Desa harus mengirimkan stafnya untuk mengikuti pendidikan dan pelatihan agar dapat menujang kemampuan staf desa dalam melaksanakan pembangunan.

Kepala Desa harus terus menjalin komunikasi yang baik dengan masyarakat desa agar asprirasi masyarakat dapat tersalurkan dalam program pembangunan.

BPD dan LPM harus terus melakukan pengawasan terhadap jalannya program pembangunan yang ada di Desa Lemahabang bisa meminimalisir jika adanya kesalahan.

\section{DAFTAR PUSTAKA}

Hasibuan, Malayu S.P. (2006). Manajemen Dasar, Pengertian Dan Masalah. Jakarta: Bumi Aksara.

Moelong. Lexy J. (2005). Metodologi Penelitian Kualitatif. Bandung: Remaja Rosdakarya.

Ndraha, Taliziduhu. Kybernologi (Ilmu pemerintahan baru). Jakarta: Rineka Cipta.

Sinabela, Poltak. (2016). Manajemen Sumber Daya Manusia
Membangun Tim Kerja Yang Solid untuk Meningkatkan Kinerja. Jakarta: Bumi Aksara.

Suharyadi, Heri dan Insani M, Aji.

Manajemen Pemerintahan

Dalam Program Unit Reaksi

Cepat Tambal Jalan Di Kota

Bandung Tahun 2015. Jurnal

Cosmogov Ilmu Pemerintahan

UNPAD, volume 2, No 2, 2016, hlm 6.

Waluyo. (2007). Manajemen Publik

Konsep, Aplikasi Dan

Implementasi Dalam

Pelakasanaan Otonomi Daerah. Bandung: CV. Mandar Maju 